Canadian University Music Review

Revue de musique des universités canadiennes

\title{
Lorraine Gorrell. The Nineteenth-Century German Lied. Portland, OR: Amadeus Press, 1993. 398 pp. ISBN 0-931340-59-4 (hardcover)
}

\section{Mario J. S. G. Champagne}

Numéro 15, 1995

URI : https://id.erudit.org/iderudit/1014402ar

DOI : https://doi.org/10.7202/1014402ar

Aller au sommaire du numéro

\section{Éditeur(s)}

Canadian University Music Society / Société de musique des universités canadiennes

\section{ISSN}

0710-0353 (imprimé)

2291-2436 (numérique)

Découvrir la revue

Citer ce compte rendu

Champagne, M. J. S. G. (1995). Compte rendu de [Lorraine Gorrell. The Nineteenth-Century German Lied. Portland, OR: Amadeus Press, 1993. 398 pp. ISBN 0-931340-59-4 (hardcover)]. Canadian University Music Review / Revue de musique des universités canadiennes, (15), 167-169.

https://doi.org/10.7202/1014402ar

All Rights Reserved @ Canadian University Music Society / Société de musique des universités canadiennes, 1995
Ce document est protégé par la loi sur le droit d'auteur. L'utilisation des services d'Érudit (y compris la reproduction) est assujettie à sa politique d'utilisation que vous pouvez consulter en ligne.

https://apropos.erudit.org/fr/usagers/politique-dutilisation/ 
Lorraine Gorrell. The Nineteenth-Century German Lied. Portland, OR: Amadeus Press, 1993. 398 pp. ISBN 0-931340-59-4 (hardcover).

While the German Lied in the nineteenth century has an extensive literature spanning almost a century, there has been a significant resurgence of interest during the past twenty to thirty years. One of the great omissions in the English language has been a solid, general overview of the genre, since many recent studies have been very specific in nature. ${ }^{1}$ The Nineteenth-Century German Lied addresses this need, although the title of the book is slightly misleading. In particular, a subtitle such as $A$ Guide to Performance, for instance, would clarify both Gorrell's intended audience and the content and tone of her book. As it stands, the browsing reader would perhaps expect to find an English analogue to Walther Dürr's Das deutsche Sololied im 19. Jahrhundert: Untersuchungen zu Sprache und Musik, ${ }^{2}$ or to Susan Youens with either of her books on Schubert and Wolf, ${ }^{3}$ or do for the German Lied what Barbara Meister did the French mélodie in The Nineteenth Century French Song: Fauré, Chausson, Duparc, and Debussy. ${ }^{4}$

What Gorrell provides the reader is something different: an historical treatise that covers the nineteenth century, focusing on the Lied, and which discusses all aspects of the history involved: cultural, political, and musical. The author guides the uninitiated reader through the repertoire with stops along the way to admire particularly impressive examples of Lieder or to point out especially lovely ones that might be unfortunately neglected and which are worthy of revival. The resulting breadth of coverage is both this book's primary strength and its greatest weakness. Dealing with such a large genre and attempting to do justice to composers who may have written hundreds of Lieder, as well as

1 For example, see Rufus E. Hallmark, The Genesis of Schumann's "Dichterliebe" : A Source Study (Ann Arbor, MI: UMI Research Press, 1979), or articles such as Christopher Hatch's "Tradition and creation: Hugo Wolf's Fußreise," College Music symposium 28 (1988): 70-84, or Franzpeter Goebel's ““. . . et audiatur altera pars': Aspekte der Lisztschen Liedtranskription,” Musik und Bildung 18, no. 4 (1986): 550-55.

2 Walther Dürr, Das deutsche Sololied im 19. Jahrhundert: Untersuchungen zu Sprache und Musik, vol. 97 of Taschenbücher zur Musikwissenschaft, edited by Richard Schall (Wilhelmshaven: Heinrichshofen, 1984).

3 Susan Youens, Hugo Wolf: The Vocal Music (Princeton: Princeton University Press, 1992) and the same author's Retracing a Winter's Journey: Schubert's Winterreise (Ithaca and London: Cornell University Press, 1991).

4 Barbara Meister, The Nineteenth Century French Song: Fauré, Chausson, Duparc, and Debussy (Bloomington: Indiana University Press, 1980). See also the same author's An Introduction to the Art Song (New York: Taplinger, 1980). 
bringing to light forgotten materials, necessarily entails a great deal of simplification and abridgement.

The opening chapters are by far the most satisfying. Covering topics such as "Poetry and Music," "Politics and Poetry," "The Piano," and "Composers, Performers, and Performances," these chapters provide a wealth of material clearly and thoroughly, setting the stage for her later discussions. Other strengths of this book are the sections dealing with "Women Musicians in Nineteenth-Century Society," an important lacuna in the historical record. Gorrell pays special attention to the work of Fanny Mendelssohn Hensel, and a separate chapter is devoted to her, both as a composer and as a performer.

The appendices of the book prove to be particularly useful. Gorrell provides a comparative chronology spanning 1720 to 1900 , summarising the main social, political, and artistic events in conjunction with the lives of poets, philosophers, and song composers. She also gives a listing of performance editions of lesser known composers' songs - very useful, indeed - and for the young performer just beginning to discover the richness of the Lied, she provides seven different possible recital programmes highlighting different facets of the repertoire.

The weakness of the book is found in most of the chapters that discuss the musical works themselves. Too much is covered too quickly and, at least to this reader, with not enough depth. I would have preferred fewer brief, superficial analyses and more in-depth discussion of one or two representative works of each composer discussed, thereby providing tools for the reader to apply to other Lieder either by the same the composer or by composers of a similar period and style. For example, when discussing Franz Schubert, Gorrell first provides a firm contextual history for his Lieder which explores Schubert's historical position, the reception of his Lieder during his own lifetime, and the struggle to have Lieder treated as a serious genre. She continues with a brief historical overview of the ballad form, using Zelter, Loewe and especially Reichard as examples (Reichardt's "Erlkönig" is discussed). Gorrel then returns to a brief exploration of Schubert's "Erlkönig" from a musical standpoint, followed by a dicussion of how performances of the song spread via its many interpreters. Two such interpreters used "Erlkönig" as a means of introducing Schubert's music abroad: Liszt (with Adolphe Nourrit) to France and Wilhelmina Schröder-Devrient to England. ${ }^{5}$ The author then moves on to discuss "Gretchen am Spinnrade" before turning to the works of other composers. The previous pattern of examination is repeated, albeit with varying stresses contingent on the composer being discussed (text-music interplay in

5 All of this material is covered in Gorrell's book in pages 112-17. 
Robert Schumann, harmonic considerations in Hugo Wolf, counterpoint in Johannes Brahms, etc.) throughout the rest of the book.

Do not mistake my intent. Gorrell's writing is clear and the non-specialist will find her narrative to be engaging. While there is much material that will benefit the young singer, the cursory nature of much of the book will limit its usefulness at the university level. While it can be recommended for use in introductory courses, the instructor would be wise to consider supplementing this source with more rigorously analytical materials.

Mario J. S. G. Champagne

Susan Rankin and David Hiley, eds. Music in the Medieval English Liturgy. Plainsong and Medieval Music Society Centennial Essays. Oxford: Clarendon Press, 1993. viii, 413 pp. ISBN 0-19-316125-7 (hardcover).

The last decade and a half has witnessed a few excellent publications of essay series on medieval and Renaissance music, among them Christian Meyer's edition of Jérôme de Moravie: un théoricien de la musique dans le milieu intellectuel parisien du XIIIe siècle (Paris: Éditions Créaphis, 1992), Iain Fenlon's edition of Music in Medieval and Early Modern Europe: Patronage, Sources and Texts (Cambridge: Cambridge University Press, 1981), and Stanley Boorman's edition of Studies in the Performance of Late Medieval Music (Cambridge: Cambridge University Press, 1983). Susan Rankin's and David Hiley's edition of Music in the Medieval English Liturgy constitutes a first-rate addition to the series of essay publications, and must be viewed as a seminal work in the area of British musical studies. This text marks the centennial year of the Plainsong and Medieval Music Society's practical and scholarly activities, since the Society's founding in 1888. Dedicated to the memory of Frank Ll. Harrison, Chair of PMMS from 1986 to 1987, and recognized as one of the giants in the field of medieval English musical research, the volume is a collection of essays, whose contents discuss diverse aspects of the monophonic and polyphonic medieval repertories in British sources, with a primary focus on chant. Following a prefatory remark by Susan Rankin, David Hiley provides a brief outline of the Society's purpose-one of reflecting musical, theological and scholarly interests, initially underlined by a desire to incorporate the wealth of the plainchant of the Roman Church into the worship of the Church of England. Hiley also provides a summary account of the Society's history, tracing from the surviving documents information concerning early membership lists, administrative management, and publishing activities from Walter Howard Frere's pioneering monumental contribu- 